\title{
Iliac Crest Autograft Harvesting by Mosaicplasty Technique
}

\section{Iliak Kanat Otogreft Alımında Mozaikplasti Tekniği}

\author{
Bulent Tanriverdi ${ }^{\oplus}$, Nezih Ziroglu ${ }^{2}$
}

${ }^{1}$ University Of Health Sciences, Bakirkoy Dr. Sadi Konuk Training And Research Hospital, Orthopaedics Clinic

${ }^{2}$ Beylikduzu State Hospital, Orthopaedics Department

Received: 23.09.2020 / Accepted: 30.03.2021 / Published Online: 31.03.2021

Cite as: Tanriverdi B, Ziroglu N. Iliac crest autograft harvesting by mosaicplasty technique. Med J Bakirkoy 2021;17(1):94-9.

\begin{abstract}
Objective: The aim of this study to present the results of patients with iliac wing autograft using the mosaicplasty method in order to reduce donor site morbidity and pain, which are two of the most common complications.

Method: Between 2011-2018, 35 patients (19 men,16 women) who were harvested autograft from the iliac wing were included in the study. The average age of patients was determined to be 42 (10-64) years, the mean follow-up was 39.9 months (12-101). All patients were operated on for pseudoarthrosis surgery. The same orthopedic surgeon harvested all autografts. The patients were evaluated at post-op 15th day, the first month, and the sixth month. Patients were evaluated in their last follow-up (at sixth month) and monofilament test, two-point discrimination test, visual analog scale (VAS), pain duration, numbness, gait problems, major pain area, cosmetic satisfaction were questioned.

Results: The mean of the monofilament test was 4.16 (2.83-6.65). The mean two-point discrimination test was $36.5 \mathrm{~mm}(9-100 \mathrm{~mm})$. The mean VAS was found to be 2.94 (1-4). In the post-op period, the duration of pain was determined as one month in 21 patients, two months in 5 patients, and four months in 2 patients, while seven patients did not complain of pain at all. It was observed that ten patients complained of numbness in the thigh region (28.5\%), and 11 patients complained of gait problem and limping (31.4\%). Fifteen patients used an assistive walking device after surgery (42.8\%). Only two patients complained of pain in the graft area when the major pain region was questioned after surgery (5.7\%). Twenty-one patients were found to be cosmetically satisfied (60\%) following the surgery scar in the graft region. Conclusion: We believe that iliac autografts taken with the mosaicplasty technique can be used safely in suitable patients (large corticocancellous graft not required) with low complication rates and high patient satisfaction.
\end{abstract}

Keywords: Autograft, iliac crest, mosaicplasty

öz

Amaç: Bu çalışmada, iliak otogreft alımı sırasında en sık karşılaşılan komplikasyonlardan olan donör saha morbiditesi ve ağrıyı azaltmak için mozaikplasti tekniği iliak otogreft alınan hastaların sonuçlarını sunmayı amaçladık.

Yöntem: Çalışmaya 2011-2018 yılları arasında iliak kanattan otogreft alınan 35 (19 erkek, 16 kadın) hasta dahil edildi. Hastaların yaş ortalaması 42 (aralık;10-64), ortalama takip süresi 39.9 ay (aralık;12-101) idi. Tüm hastalar psödoartroz cerrahisi için ameliyat edildi ve tüm otogreftler aynı ortopedik cerrah tarafından alındı. Hastalar post-op 15. gün, 1. ay ve 6. ayda değerlendirildi. Hastalar son takiplerinde monofilaman testi, iki noktalı ayrımı testi, visüel analog skala (VAS), ağrı süresi, uyuşma, yürüme sorunları, majör ağrı bölgesi, kozmetik memnuniyet ve gerektiğinde yeniden greft alınmasına izin verip vermeyecekleri açısından sorgulandı.

Sonuç: Monofilaman testinin ortalaması 4,16 (2,83-6,65) idi. Ortalama iki noktalı ayrım testi 36,5 mm (9-100 mm) idi. Ortalama VAS 2,94 (1-4) olarak bulundu. Ameliyat sonrası dönemde ağrı süresi 21 hastada 1 ay, 5 hastada 2 ay, 2 hastada dört ay olarak belirlenirken, yedi hastada hiç ağrı şikayeti olmadı. On hastanın uyluk bölgesinde (\% 28,5) uyuşma, 11 hastanın ise (\% 31,4) yürüme sorunu ve aksamadan şikayet ettiği görüldü. On beș hasta ameliyattan sonra yardımcı yürüme cihazı kullandı (\% 42,8). Ameliyat sonrası majör ağrı bölgesi sorgulandığında sadece iki hasta greft bölgesinde ağrıdan şikayet etti (\% 5,7). Greft bölgesindeki ameliyat izi sonrası 21 hastanın kozmetik olarak memnun olduğu (\% 60) bulundu.

Tartışma: Mozaikplasti tekniği ile alınan iliak otogreftlerin büyük kortikokansellöz greft gerekmeyen uygun hastalarda düşük komplikasyon oranları ve yüksek hasta memnuniyeti ile güvenle kullanılabileceğine inanıyoruz.

Anahtar kelimeler: Otogreft, iliak kanat, mozaikplasti

Corresponding Author:

drbulenttanriverdi@gmail.com
B. Tanriverdi 0000-0001-8931-9189 N. Ziroglu 0000-0002-2595-9459

(C) Telif hakkı Sağlık Bilimleri Üniversitesi Bakırköy Dr. Sadi Konuk Eğitim ve Araştırma Hastanesi'ne aittir. Logos Tıp Yayıncılık tarafından yayınlanmaktadır. Bu dergide yayınlanan bütün makaleler Creative Commons Atff-GayriTicari 4.0 Uluslararası Lisansı ile lisanslanmıştır.

(c) Copyright Health Sciences University Bakırköy Sadi Konuk Training and Research Hospital. This journal published by Logos Medical Publishing.

Licenced by Creative Commons Attribution-NonCommercial 4.0 International (CC BY) 


\section{INTRODUCTION}

In orthopedic surgery, autograft is used frequently in pseudoarthrosis treatment, and iliac wing comes to the fore as the largest donor site with osteoconductive and osteoinductive characteristics. ${ }^{(1)}$ Despite the widespread use of iliac wing; the need for a second incision, pain in the donor site, neurological injury, vascular injury, deep tissue infection, extensive hematoma, intestinal herniation, and secondary fracture were proposed as disadvantages associated with obtaining these autografts. ${ }^{(1,2)}$ In the literature, minor complications have been reported as $6-39 \%$, and major complications have been reported as $0.7-$ $25 \% .^{(3-9)}$ Pain is the most common reported complication. It has been reported that $31 \%$ of patients with tricortical graft harvested can complain pain even two years after surgery. ${ }^{(10)}$

Since the autograft is indispensable for pseudoarthrosis surgery, it is very important to minimize the mentioned complications. The iliac autograft, which will be harvesting with a smaller incision and less damage to the bone, may facilitate avoiding these complications. With this hypothesis, we planned to obtain autografts using the smallest possible incision and mosaicplasty apparatus.

In this study, we aimed to present the results of patients in whom iliac wing autograft was obtained with a mosaicplasty apparatus in order to reduce donor site morbidity and pain, which are two of the most common complications.

\section{PATIENTS AND METHOD}

The approval of the institutional ethical committee (no. 2019-21-06) was received on October 28, 2019 for this study. Informed consent was also obtained from the patients.

In this retrospective study, between 2011-2018, 35 patients (19 men, 16 women) who were harvested autograft from the iliac wing were included in the study. The average age of patients was determined to be 42 (range; 10-64) years. The mean follow-up was 39.9 months (range; 12-101). All patients were operated on for pseudoarthrosis surgery. The same orthopedic surgeon harvested all autografts. After

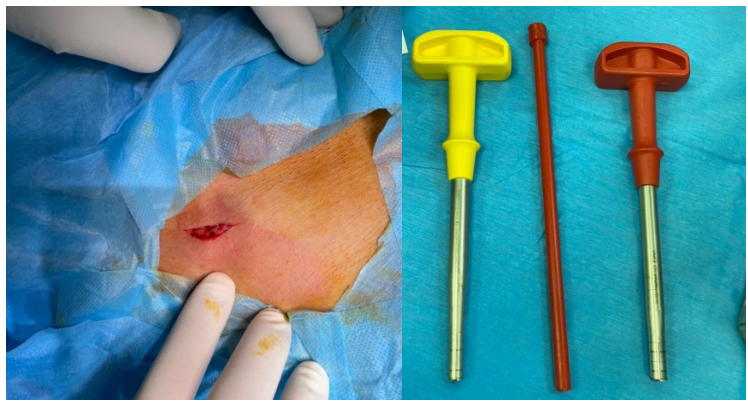

a

b

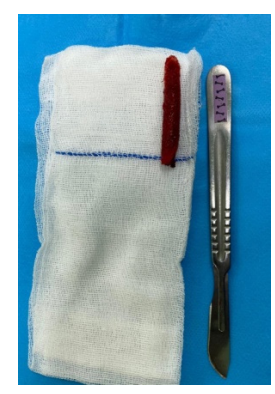

c

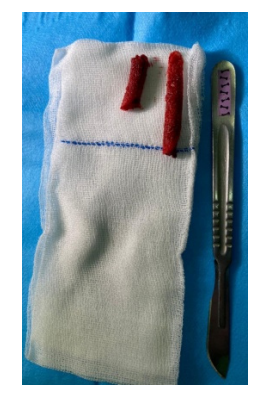

d

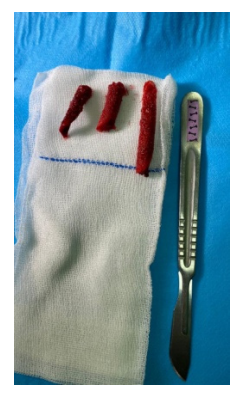

e
Figure 1. Mini incision for graft harvest (a), mosaicplasty apparatus (b) and harvested autografts (c,d,e).

performing a small incision on the iliac wing, the iliac bone was reached. Then, the appropriate diameter of the mosaicplasty graft apparatus was driven deep into the spongiosis area from the superior edge of the iliac wing. When appropriate depth of graft was harvested, it was removed by turning it to the right and left, and then the autograft was gained. In case of need, the graft apparatus was directed to the right and left through the same hole, and additional grafts were harvested (Figure 1). When the need was higher, new entries were applied from other points to increase the amount of graft. After the graft harvesting was completed, the incision was sutured. Drains were placed in patients (22 patients) when needed (simple mini vacuum drain). All drains were removed within 24 hours. During the postoperative period, routine antibiotics and pain medication were applied. No local anesthetic or anti-bleeding agent was applied to the graft incision area. The incision length was found to be $44.5 \mathrm{~mm}(15-85 \mathrm{~mm})$ on average.

While 26 grafts were harvested unilaterally the same to the surgical side, eight patients were harvested bilaterally and one patient from contralaterally. In terms of smoking and comorbidities, 14 of our 
Table 1. Incision, monofilament test, two-point discrimination and VAS values of patients.

\begin{tabular}{|c|c|c|c|c|}
\hline Patient & $\begin{array}{l}\text { Incision } \\
\text { (mm) }\end{array}$ & $\begin{array}{l}\text { Monofilament } \\
\text { test }\end{array}$ & $\begin{array}{l}\text { Two point } \\
\text { discrimination }\end{array}$ & VAS \\
\hline 1 & 40 & 4,31 & 25 & 3 \\
\hline 2 & 25 & 3,61 & 35 & 3 \\
\hline 3 & 30 & 3,61 & 35 & 3 \\
\hline 4 & 30 & 4,31 & 45 & 4 \\
\hline 5 & 20 & 2,83 & 30 & 4 \\
\hline 6 & 10 & 2,83 & 30 & 4 \\
\hline 7 & 50 & 2,83 & 10 & 4 \\
\hline 8 & 60 & 4,31 & 45 & 4 \\
\hline 9 & 5 & 2,83 & 25 & 4 \\
\hline 10 & 45 & 3,61 & 30 & 2 \\
\hline 11 & 50 & 4,31 & 100 & 2 \\
\hline 12 & 14 & 4,56 & 20 & 2 \\
\hline 13 & 55 & 4,31 & 40 & 3 \\
\hline 14 & 65 & 4,56 & 65 & 4 \\
\hline 15 & 46 & 4,56 & 75 & 3 \\
\hline 16 & 55 & 6,65 & 15 & 4 \\
\hline 17 & 50 & 4,31 & 50 & 3 \\
\hline 18 & 32 & 3,61 & 25 & 2 \\
\hline 19 & 55 & 4,56 & 55 & 4 \\
\hline 20 & 75 & 4,56 & 60 & 4 \\
\hline 21 & 40 & 6,65 & 80 & 3 \\
\hline 22 & 85 & 4,56 & 25 & 3 \\
\hline 23 & 55 & 3,61 & 25 & 2 \\
\hline 24 & 40 & 4,31 & 13 & 3 \\
\hline 25 & 45 & 4,31 & 44 & 3 \\
\hline 26 & 43 & 4,31 & 45 & 3 \\
\hline 27 & 42 & 2,83 & 20 & 1 \\
\hline 28 & 60 & 4,56 & 9 & 2 \\
\hline 29 & 47 & 4,31 & 30 & 2 \\
\hline 30 & 43 & 4,56 & 32 & 2 \\
\hline 31 & 60 & 4,31 & 23 & 2 \\
\hline 32 & 44 & 3,61 & 26 & 3 \\
\hline 33 & 46 & 3,61 & 26 & 3 \\
\hline 34 & 50 & 4,31 & 20 & 3 \\
\hline 35 & 30 & 4,56 & 45 & 2 \\
\hline
\end{tabular}

patients were smokers, and three patients had diabetes mellitus (DM).

The patients were evaluated for routine controls at 15th day and 30th day postoperatively. Patients were evaluated in their last follow-up (at sixth month) and monofilament test, two-point discrimination test, visual analog scale (VAS), pain duration, numbness, gait problems, major pain area, cosmetic satisfaction were questioned. If needed the patients were asked whether they would allow re-graft harvesting. The monofilament test is used to test the sense of touch. It is made with nylon filaments of approximately the same length, different colors, and varying diameters (between 1.65 and 6.65). Failure to react with 6.65 of them indicates numbness. In the two point discrimination test, the perception of two separate points that are touched to the skin at the same time is evaluated. Eyes must be closed during the examination. These distances vary in different body regions. ${ }^{(11)}$ In the assessment of pain by VAS, 1 indicates the mildest pain and 10 the most severe pain. The patient is asked to evaluate the pain between 1 and 10, and this value is recorded. All tests were performed by the same orthopedic surgeon in our outpatient clinic. During the writing of the study, patients were called by phone and questioned whether there was a change in their condition.

As a statistical method, frequency and percentage values were given for categorical variables. Mean, standard deviation, median, minimum and maximum values were given for continuous variables. Normal distribution testing of continuous variables was conducted by using the Kolmogorov Smirnov test. In the variables that did not perform the normal distribution assumption, the Mann Whitney $U$ test was used in the comparison of two independent groups, and Spearman correlation analysis was used to determine the correlational relationships between the variables that did not provide the normal distribution assumption. $\mathrm{P}<0.05$ was considered statistically significant.

The analyzes were done with NCSS 11 (Number Cruncher Statistical System, 2017 Statistical Software) Program.

\section{RESULTS}

The mean of the monofilament test was 4.16 (2.83$6.65)$. The mean two-point discrimination test was $36.5 \mathrm{~mm}(9-100 \mathrm{~mm})$. The mean VAS was found to be 2.94 (1-4). In the post-op period, the duration of pain was determined as one month in 21 patients, two months in 5 patients, and four months in 2 patients, while seven patients did not complain of pain at all. It was observed that ten patients complained of numbness in the thigh region (28.5\%), and 11 patients complained of gait problem and limping (31.4\%). Fifteen patients used an assistive walking device after surgery (42.8\%). Only two patients complained of pain in the graft area when the major pain region was questioned after surgery (5.7\%). Twenty-one patients were found to be 
cosmetically satisfied (60\%) following the surgery scar in the graft region. All of the patients stated that they would approve if a graft harvesting is required again (100\%). In the phone call, where their latest status was questioned, it was determined that our patients had no problems with numbness, limping and walking, and they had no complaints about graft surgery.

Statistically, there was a significant difference in monofilament levels according to smoking. ( $p=$ $0.040, p<0.05)$. Smokers have a higher monofilament level.

In a two-point discrimination measurement, it was found that the patients with hip/thigh numbness was significantly higher than those without that $(p=$ 0.020, $p<0.05$ ). Besides, a two-point discrimination test measurement was found to be significantly higher in patients with claudication/gait impairment than those without ( $p=0.001, p<0.05)$.

The monofilament level (Semmes Weinstein monofilament test) of cases with an incision length of $30 \mathrm{~mm}$ and above was found to be statistically and significantly higher than that of cases below $30 \mathrm{~mm}$ ( $p=0.001, p<0.05)$.

\section{DISCUSSION}

In orthopedic surgery practice, autograft use is quite effective and mandatory in some surgeries. Harvesting these grafts, which has an important role in daily practice, with methods that will cause less morbidity can both make their use more common, and help patients accept this procedure more easily and overcome the post-op process faster and easier. We think that the our harvesting method reduces pain, scar tissue, and complications due to donor site morbidity.

Pain is the most frequently reported complication after iliac autograft harvest, and acute pain lasting less than six weeks has been reported to occur in $62 \%$ of patients. ${ }^{(12)}$ Many hypotheses have been proposed regarding the etiology of pain. Some authors have argued that damage to nearby neurological structures may be accused during grafting. ${ }^{(9,13)}$ Turner et al. reported chronic pain as the most common complication in 47 patients who were treated with iliac crest bone graft. ${ }^{(14)}$ Goulet et al. reported the incidence of pain in their patients at $37.9 \%$ during their 6-month follow-up and stated that $18.7 \%$ of the patients' pain continued in the second year as well. ${ }^{(15)}$ Summers et al. argued that the pain at the donor site was related to the way the graft harvesting and reported that the pain prevalence was higher in patients who harvested a tri-cortical full-thickness graft compared to those who harvested a bi-cortical graft, and also reported that up to $31 \%$ patients had chronic pain two years after the procedure. ${ }^{(10)}$ Ahlmann et al. reported that anterior graft harvest was significantly more associated with long-term pain than posterior graft harvest. ${ }^{(16)}$ The limitation of our study is that it does not allow comparison of anterior and posterior graft harvesting in terms of pain and functional problems. In the procedures performed with the mosaicplasty apparatus, compared to the bi-tri cortical grafting procedures, the cortical area is harvested to the diameter of the extractor apparatus (diameter between $5-10 \mathrm{~mm}$ ), and the donor site morbidity is minimized. Besides, according to the anticipated graft need, the incision is kept short, and possible sensory complications are avoided. In particular, only $5.7 \%$ of patients complained of donor site pain compared to the major surgical site. We detected pain lasting longer than one month in 7 of our patients (20\%). None of our patients had pain that lasted longer than four months.

Another problem after iliac autograft harvesting is cosmetic complaints. Shin et al. reported that they generally achieved a satisfactory cosmetic result because the lateral part of the iliac wing remained intact, and the surgical scar was left in the area of the skin lines. ${ }^{(1)}$ Similarly, our study reported high cosmetic satisfaction, due to the use of a small incision, 21 (60\%) of our patients were found to be cosmetically satisfied with the scar in the graft area. The fact that all our patients express that they can allow re-graft harvesting, if necessary, can be considered as a subjective finding that shows the relationship between this method with high patient satisfaction and low morbidity. Also, there was a statistically significant positive correlation between the incision length and the monofilament test $(p=0,001)$. This finding favorably supports the our 
method that we use for graft harvesting.

The most frequently reported functional problem after grafting is ambulation. In many publications, difficulty in gait or weight-bearing has been reported in patients who underwent iliac grafting surgery, and gluteal gait pattern is the most frequently reported ones in approximately $3 \%$ of patients. ${ }^{(9,17)}$ Kurz et al. stated that after posterior grafting, patients complained of weakness in climbing the stairs and standing up from a sitting position. ${ }^{(9)}$ In our study, 11 patients (31\%) complained about gait disturbance and limping in the early post-operative period. Fifteen of patients (42\%) used an assistive device while walking.

Complications that may require secondary intervention such as neurological injury, vascular injury, deep tissue infection, extensive hematoma, intestinal herniation, secondary fracture, and pelvic instability after grafting have been reported in the literature at the rate of 2.5-39\%. Minor complications that do not require any intervention have been reported at the rate of $10-40 \%{ }^{(18)}$ Sandor et al. reported the rate of intraoperative complications as $1.2 \%$ and postoperative complications as $3.6 \%$ in 84 patients who used trephine for grafting. ${ }^{(19)}$ As we indicated in our study, the use of trephine, as an example of a minimally invasive method, has low complication rates. We did not encounter any complications such as bleeding, fracture, wound infection in any of our patients.

The weaknesses and limitation of our study are the retrospective concept, the small number of patients, and the lack of a comparison group. However, all the grafts were harvested by the same orthopedic surgeon with the mosaicplasty method, follow-up times were at least one year, and objective scales such as the two-point discrimination test with the monofilament test as well as subjective parameters were used for evaluation. To the best of our knowledge, there are no other studies in the literature in which the monofilament test and the two-point discrimination test were performed to evaluate iliac crest autografts. Although the mosaicplasty technique seems to be a suitable method for obtaining cancellous bone grafts, it should be kept in mind that larger corticocancellous autografts may be required in the treatment of long bone pseudoarthrosis. Therefore, this method should be preferred for appropriate cases.

In conclusion, we believe that graft harvesting with the mosaicplasty apparatus can be safely used in appropriate cases with low complication rates and high patient satisfaction, thereby increasing the acceptability and use of the iliac autograft.

Ethics Committee Approval: Non-Invasive Research Ethics Committee approval was obtained from Bakirkoy Dr. Sadi Konuk Training and Research Hospital (28.10.2019/2019-21-06).

Conflict of Interest: The authors declare no conflicts of interest with respect to the authorship and/or publication of this article.

Funding: None.

Informed Consent: Informed consent form was obtained from the patients.

\section{REFERENCES}

1. Shin SR, Tornetta III P. Donor Site Morbidity After Anterior Iliac Bone Graft Harvesting. J Orthop Trauma 2016;6:340-3. doi: 10.1097/BOT.0000000000000551

2. Kim DH, Rhim R, Li L, Martha J, Swaim BH, Banco RJ et al. Prospective study of iliac crest bone graft harvest site pain and morbidity. The Spine Journal 2009;9;886-92. https://doi.org/10.1016/j.spinee.2009.05.006

3. Keller EE, Triplett WW. Iliac bone grafting: Review of 160 consecutive cases. J Oral Maxillofac Surg 1987;45:11-4 DOI: 10.1016/0278-2391(87)90079-6

4. Sawin PD, Traynelis VC, Menezes AH. A comparative analysis of fusion rates and donor-site morbidity for autogeneic rib and iliac crest bone grafts in posterior cervical fusions. J Neurosurg 1998;88:255-65. DOI: $10.3171 /$ jns.1998.88.2.0255

5. Younger EM, Chapman MW. Morbidity at bone graft donor sites. J Orthop Trauma 1989;3:192-5. DOI: 10.1097/00005131-198909000-00002

6. Arrington ED, Smith WJ, Chambers HG, Bucknell AL, Davino NA. Complications of iliac crest bone graft harvesting. Clin Orthop Relat Res 1996;329:300-9. DOI: 10.1097/00003086-199608000-00037

7. Canady JW, Zeitler DP, Thompson SA, Nicholas CD. Suitability of the iliac crest as a site for harvest of autogenous bone grafts. Cleft Palate J 1993;30:579-81. DOI: 10.1597/1545-1569_1993_030_0579_sotica_2.3.co_2

8. Banwart JC, Asher MA, Hassanein RS. lliac crest bone graft harvest donor site morbidity: a statistical evaluation. Spine 1995;20:1055-60. DOI: 10.1097/00007632-199505000-00012

9. Kurz LT, Garfin SR, Booth RE. Harvesting autogenous iliac bone grafts: a review of complications and techniques. Spine 1989;14:1324-31 DOI: 10.1097/00007632-198912000-00009

10. Summers BN, Eisenstein SM. Donor site pain from the ilium: a complication of lumbar spine fusion. J Bone Joint Surg $\mathrm{Br}$ 1989;71:677-80. PMID: 2768321 
11. Bell-Krotoski J, Weinstein S, Weinstein C. Testing sensibility, including touch-pressure, two-point discrimination, point localization, and vibration. J Hand Ther. 1993 Apr-Jun;6(2);114-23. doi: 10.1016/s0894-1130(12)80292-4.

12. Pollock R, Alcelik I, Bhatia C, Chuter G, Lingutla K, Budithi C et al. Donor site morbidity following iliac crest bone harvesting for cervical fusion: a comparison between invasive and open techniques. Eur J Spine 2008;17:845-52. DOI: 10.1007/s00586-008-0648-3

13. Colterjohn N, Bednar D. Procurement of bone graft from the iliac crest. An operative approach with decreased morbidity. J Bone Joint Surg Am. 1997;79A:756-9.

DOI: 10.2106/00004623-199705000-00016

14. Turner JA, Ersek M, Herron L, Haselkorn J, Kent D, Ciol MA et al. Patient outcomes after lumbar spinal fusions. JAMA 1992;268:907-11. PMID: 1640622 https://doi.org/10.1001/jama.268.7.907

15. Goulet JA, Senunas LE, DeSilva GL, Greenfield ML. Autogenous iliac crest bone graft. Complications and functional assessment. Clin Orthop Relat Res. 1997;(339):76-81.

DOI: 10.1097/00003086-199706000-00011
16. Ahlmann E, Patzakis M, Roidis N, Shepherd L, Holtom P. Comparison of anterior and posterior crest bone grafts in terms of harvest-site morbidity and functional outcomes. J Bone Joint Surg Am. 2002; 84:716-20.

DOI: 10.2106/00004623-200205000-00003

17. Converse JM, Campbell RM. Bone grafts in surgery of the face. Surg Clin North Am 1954;34:375-401. DOI: 10.1016/s0039-6109(16)34187-1

18. Russell JL, Block JE. Surgical harvesting of bone graft from the ilium: point of view. Med Hypotheses 2000;55:474-9. DOI: 10.1054/mehy.2000.1095

19. Sandor GK, Rittenberg BN, Clokie CM, Caminiti MF. Clinical success in harvesting autogenous bone using a minimally invasive trephine. J Oral Maxillofac Surg. 2003;61(2):164-8.

DOI: 10.1053/joms.2003.50042 